\title{
ENVISIONING OPEN-AIR MUSEUM FOR INDONESIAN
}

\author{
Yusfan Adeputera Yusran \\ Department of Architecture, Universitas Brawijaya, Malang, Indonesia 65145 \\ Email: yusfan@ub.ac.id
}

\begin{abstract}
The founding of Skansen in the early of the 19th century was a milestone behind the phenomenon of Open-air museums all over the world. Although late, this phenomenon began to emerge in Indonesia since 1972 marked by the establishment of Taman Mini Indonesia Indah (TMII). Behind all the controversy on its establishment, TMII has been recognized as one of the nation pride as well as the first instituted open-air museum in the country. Ahead, this noble purpose should be further envisaged as an opportunity for Indonesian to take a part in rescuing remaining vernacular houses as the provision for future generations recognize their identity. By observing TB Silalahi Center in Balige and Taman Nusa in Gianyar, this paper describes that the opportunity for Indonesian to conserve ex-situ their neglected vernacular houses also definitely could be realized. From the analysis, some constraint found in terms of management, specifically in financial issue, but proven does not make a significant barrier in making these both museums keep running. Need collaboration from related parties since there is no proper translocation procedure done and also the weaknesses of tangled documentation. This concern aroused in order to prospecting ex-situ conservation for Indonesian vernacular houses properly implemented as an Open-air museum.
\end{abstract}

Keywords: Indonesian open-air museum; ex-situ conservation; vernacular houses.

\section{INTRODUCTION}

The open-air museum is not a new thing in the western world. In Europe, Skansen founded by Arthur Hazelius in 1891, has been instituted as the first openair museum in the world and the first in what became a Europe-wide movement in preserving vernacular houses. Debates behind maintaining the value of cultures in-situ extensively have been controversial since the beginning of this phenomenon exists. Evoking the spirit of place arises question when the desire to save the civilization race against time. All abandoned vernacular houses are clear evidence when a human does not want to continue living in backwardness. Globalization has dragged civilization to share modernization, including transform how we live today.

In Indonesia, auspiciously, several foundations have intensified the salvage of vernacular houses across Indonesia. Mention to Yayasan Rumah Asuh and its collaboration with the Tirto Utomo Foundation and some philanthropists behind. These partnerships seek to restore the former glory of the cultural heritage of Nusantara society by helping them rebuild their traditional house (Yusran, 2016). Be grateful for the vernacular houses that still have indigenous residents who still stand by their culture, as hitherto sustained by them continously, as found at Waerebo, Ratenggaro, Nias and Toro. In contrast with some traditional houses that settled in the middle of a neighborhood with modern-titivated houses, especially in the villages which began to be modernized as city-like, as seen in Dokan and Lingga. Here, these houses are only waiting to be abandoned decayed or demolished for firewood.

In Europe, attempt to preserve this kind of houses has been continually occurring, even in fact, being an integrated concept with cultural conservation so thus regulated stringently. By translocate their vernacular houses that no longer occupied to a new place, proven has positive values in maintaining their cultural and historical heritage. Beside as learning center, these new sites presented as new tourist attractions in the form of an open-air museum and became a reference for other non-European countries to develop this kind of institutions. Now, it also becomes a new research center for various fields of study like culture, history, construction, dendrology, and so forth.

In Indonesia, undeniable, TMII instituted as the first open-air museum, as a reference in introducing the cultural visage of Indonesia as a whole. But unfortunately, those displayed diverseness are credolously represented by only 'decorous' and 'beautifulness' expressive cultures. Amongst the falsehood, not all Indonesian cultures performed there. Only which state as a unique king/noble-version houses that considered representing each province was displayed here. Albeit with simply make-up and an excessively polishes everywhere (Kerlogue, 2008), TMII could prominently to exhibit the cultural diversity of Indonesia. This effort should be appreciated, at least what had dreamt and said by the ex-president Soeharto and his wife, Mrs. Tien turn into the reality 
nowadays, where all of TMII's collections has been undoubtedly showing its 'antiquity' with all its distinguished purposes.

But now, a glimmer of hope slightly untied by several efforts in translocating vernacular house. Some peoples have started to implement the open-air museum concept, as seen at the TB Silalahi Center in Balige, Sumatera Utara and Taman Nusa in Gianyar, Bali. Although there are many challenges in its implementation, these efforts should be continued amid many vernacular houses were suffered and left decayed.

\section{LITERATURE REVIEW}

Until now, identified approximately more than 2000 open-air museums in Europe (Czajkowski in Rentzhog, 2007:195), and mostly as the pioneer of its kind in the respective country. This phenomenon was started with the founding of Skansen in Stockholm in 1891. Starting from the wrath of Arthur Hazelius to European conditions at the time where peoples start abandoning their vernacular houses due to modernization (Rentzhog, 2007). This phenomenon was the result of reworking which carried out by Scandinavian countries such as Norway, Finland and Denmark. Thus why the 'Skansenology', or the phenomenon of open-air museum may be assumed came from Scandinavian. Such phenomenon also arouses in England, where the industrial revolution triggered the society at that time began to leave wooden house and move on to the brick (Atkinson, 1987). It also affects the European mainland, where revolution as a result of the world war became the basis of the importance to saves the past (Oliver, 2001). Thus, many declarations from the ethnologist and anthropologist at the time had envisioned the importance of preserving the past for future generation (Rentzhog, 2007).

While in Indonesia, TMII that based on the concept of beautiful Indonesia in miniature, being the first as instituted open-air museum. With ' growth and development project' concept, TMII built by expanding formerly $145 \mathrm{Ha}$ land into $394 \mathrm{Ha}$ to accommodate buildings consists of; pavilion area, museums, monuments, infrastructure and facilities (Raswaty, 2009). With all the controversy behind its establishment, TMII has been considered to represent nation's cultures, especially at that time when Indonesia still struggling out of the political, economic, social, and cultural crisis (Hitchcock, 2005).

In Indonesia, by her research, Retno Raswaty (2009) has classified TMII as an open-air museum. Albeit less in the term of authenticity of the architectural features since dominated by reenactment buildings, TMII meets the criteria due to its displayed features and purposes. These criteria consist of; building features, purposes, location, collection, and exhibition. These criteria determined based on her identification towards the definition of open-air museum by the International Council of Museums (ICOM) and the Association of European Open-air Museums (AEOM).

Open-air museum usually refers to an open area consist of historical object collections in the form of settlement, public open space, buildings or a trade complex that integrally arranged on a unique site. There are several characteristics that distinguish between open-air museum with historical area, i.e.: consists of some buildings/outdoor collections, the represented buildings shows preceding historical period, these buildings are the main theme of the exhibition and open to public in a scheduled daily program; and its purpose as an educational institution (Angotti in Raswaty, 2009).

Its location in the open space does not necessarily have a connection with the collected objects. These collections usually consist of architectural elements (house, barn, ornament, decoration, etc) and popular culture from pre-industrial era and industrial revolution. It also include architectural works and objects that represent a particular genre of the historical period in a given area, which has moved, reconstructed, and collected in a specific location and utilized for the museum (Raswaty, 2009).

Table 1. Criteria for Open-air Museum

\begin{tabular}{cl}
\hline $\begin{array}{c}\text { Aspect of } \\
\text { Open-air } \\
\text { Museum }\end{array}$ & \multicolumn{1}{c}{ Description } \\
\hline Features & $\begin{array}{l}\text { Elements of architecture and popular culture } \\
\text { from pre-industrial and industrial revolution, } \\
\text { as well as great works of architecture that } \\
\text { cannot be conserved on the original } \\
\text { site/location }\end{array}$ \\
Purposes & $\begin{array}{l}\text { Public orientation which manifested as } \\
\text { knowledge features about the settlement, }\end{array}$ \\
life, building or trading places that shown \\
integrally in an open space
\end{tabular}

(Source: Raswaty, 2009) 
Meanwhile, the performance of the open-air museum accentuates on the visual quality of the building style and landscape design. Building typologies and its equipment are also an important thing. All objects are presented to portray the diversity of architecture so take visitors in experiencing the past as well as the culture through interactive involvements such as the use of costumes, making of handicrafts, traditional industrial processes, or daily life of a community through traditional household appliances (Raswaty, 2009). All of these criteria has summarized in Table 1.

To understand whether this definition could be applied to the open-air museums that conserve vernacular houses in an ex-situ manner in Indonesia, then conducted an analysis of two cases of open-air museum, the Huta Batak at TB Silalahi Center in Balige, Sumatera Utara and the Cultural Village at Taman Nusa in Gianyar, Bali.

\section{Huta Batak in TB Silalahi Center}

What TB Silalahi center (TBSC) had done in Balige, Sumatera Utara could give an image of how those abandoned vernacular houses surrounding Lake Toba has succesfully preserved in an ex-situ manner. In Toba, some villagers that still have a vernacular house keep trying to maintain their inherited heritage. However, economic snags that wrap them become the significant deterrent to keep these houses remain standing. Finally, many of those houses are left unkempt, and over time, just left decays and lastly collapse.

Be aware of that, TBSC realized by Major General (ret) TB Silalahi on 7 August 2006 as a response to sustain Batak's culture and its heritage. Besides, the museum also intended to unify six puak (families) of Batak, i.e. Toba, Karo, Simalungun, Mandailing, Pak-pak, and Angkola. This museum is expected to raise the dignity and quality of Batak's culture, especially for future generations. With this vision, TBSC built as a complex that consists of TB Silalahi's history museum, which first settled, that stood in former factory buildings (figure 1a). Then, followed by the museum Batak (the last new building) that contains many Batak's relics from various locations (figure 1b), and the Huta Batak (figure 1c), which has built consecutively. So, these buildings were not settled at the same time.

One of interesting point in TBSC is the Huta. The Huta Batak of TBSC is presenting an outdoor museum that shows the antiquity of the Batak tribe village. Huta means a compound of several Batak homes that once has inhabited by a small group of people who are still in one clan or descent (or little clan-based village). The Huta Batak of TBSC consists of three Ruma (Jabu) and four Sopo, which are hundreds of years old aged. These abandoned houses were donated from various clan that live around Toba Lake to be saved and treated at TBSC. But, actually, in return, the owner of these Ruma and Sopo awarded compensation in the range of 40-50 million rupiahs for each building.

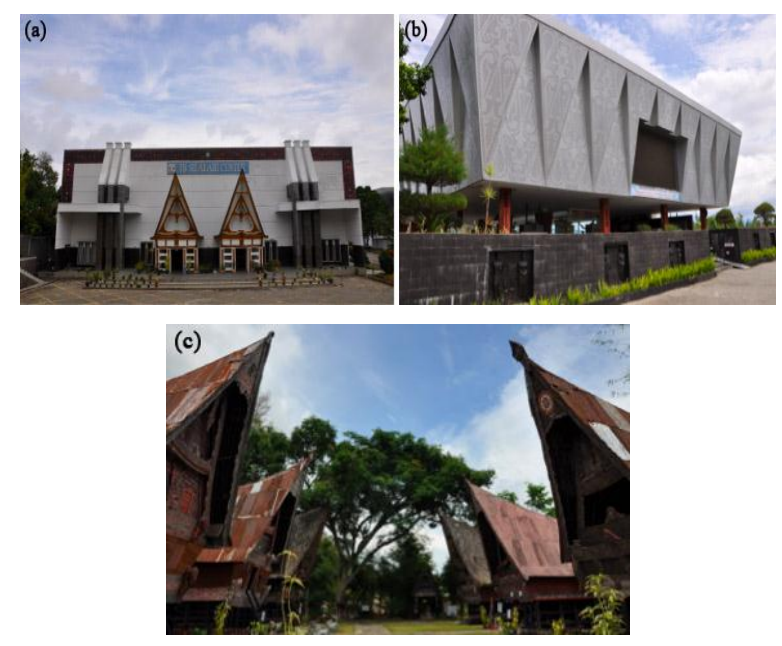

Fig. 1. (a) TB Silalahi's History museum (b) Museum Batak (c) Huta Batak

These Ruma and Sopo were initially translocated and reassembled at the museum. It was easier, because these buildings using knockdown system (without nail). These buildings are placed on a squareshaped site and conditioned as Huta with a new-made entrance gate and surrounded by bamboo plants as the fence to portray the actual situation of the Huta. On January 18, 2011, President Susilo Bambang Yudhoyono inaugurated it as a part of TBSC museum.

Right in front of the Huta (figure 2a), stands a Tongkonan (Toraja's traditional house). This Tongkonan was built as a symbol of the relationship between the Toraja's ancestors and the Batak (according to the museum's manager). This identification physically can be seen from the buffalo horn mounted on the ridge of the Huta, which also found in the Tongkonan, shows the social strata of the owners.

Not far from the Huta, in the front of Tongkonan, stands the Siwaluh jabu (the Karo's house), which is also a donation and re-established at the site in 2011 (figure 2b). There were many adjustments and lots of improvement, especially in the roof with new fibers and the exterior, which was repainted overall. Its sub-structure part was painted in black as a result of diesel fuel applied to prevent termites. This Siwaluh Jabu is not accessible for safety reasons, since the structure analyzed not quite strong in bearing live load. 


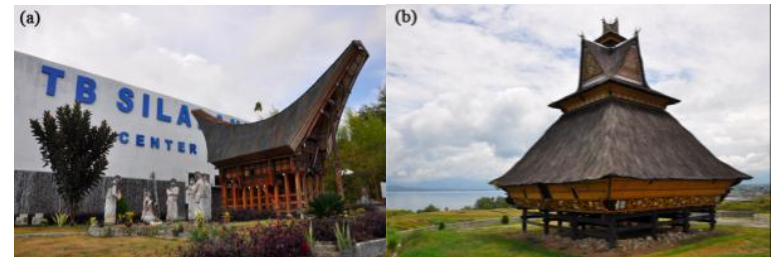

Fig. 2. (a) New Tongkonan at TBSC (b) Relocated Siwaluh Jabu at TBSC

In order to sustain the culture, TBSC often held cultural festival, such as carving contest in making the Gorga (Batak's ornament). This festival held annually adjusted with the museum's anniversary. The festival itself enlivened by peoples around the Tobasa district, dominantly students in order to encourage them to learn the culture and take part to manage the museum through internships and volunteering program that offered by TBSC management.

\section{Taman Nusa Bali}

Meanwhile, in the eastern part of Indonesia, efforts to save Nusantara vernacular houses exsitucally also resonate in Taman Nusa Bali (figure 3).
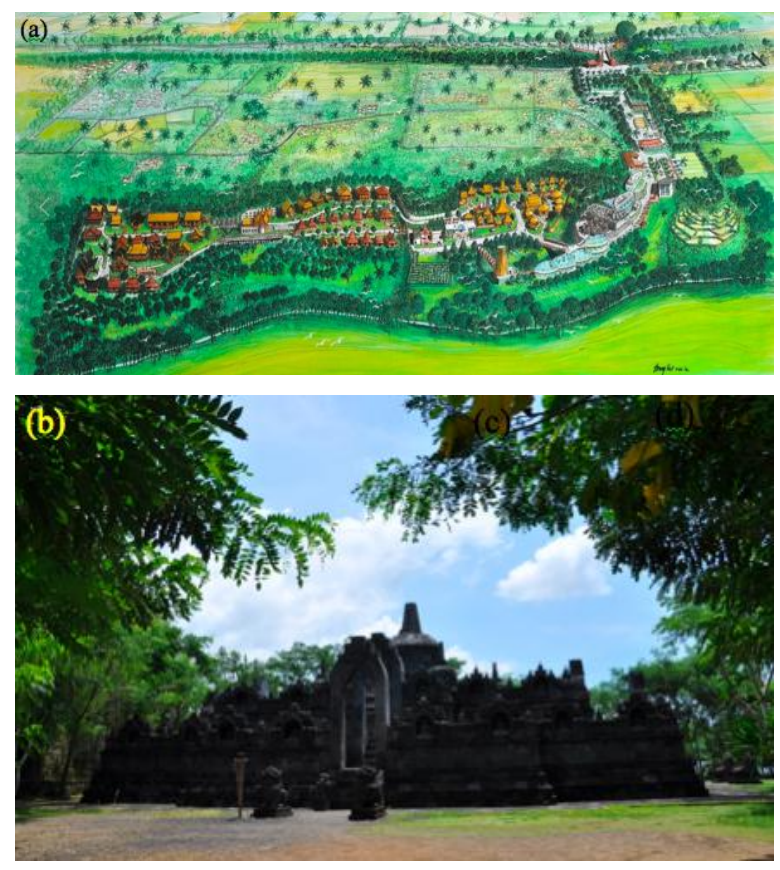

Fig. 3. (a) Taman Nusa map (b) Borobudur miniature at Taman Nusa (Source: taman-nusa.com and author)

Taman Nusa is located in Sidan village, Gianyar $30 \mathrm{~km}$ northeast of Denpasar, Bali. With the slogan, 'See Indonesia in one afternoon', Taman Nusa intend to show the diversity of Indonesian culture and history in a half day. This option was offered to attract tourists, especially for those whose belonging to a tour trip.
Taman Nusa publically launched since 10 July 2013. But the process of construction itself has been carried out since 2008. Regarding the idea of establishing Taman Nusa, the founder Santoso Senangsyah, a businessman, states himself inspired from Taman Mini Indonesia Indah. On 15 hectares of distinctive contoured Gianyar land, standing 60 traditional buildings which mainly built on site by the original builders that brought from their respective regions. Only 11 hectares used for building and infrastructure, the remaining four set aside to conserve the woods in cooperation with the villagers around the sites. But what made the difference from TMII is, among its collection, there are several native houses were flown here from its original location (figure 4), ie: а Вапиа Layuk from Mamasa, a 100-year-old Limas house from Plaju in Palembang, several Tongkonan from Toraja, a 70 year old Rumah Gadang from Padang, Blora house, and a 19th century Javanese-style Pendopo from Yogyakarta. These entire original houses were purchased directly from its owners.

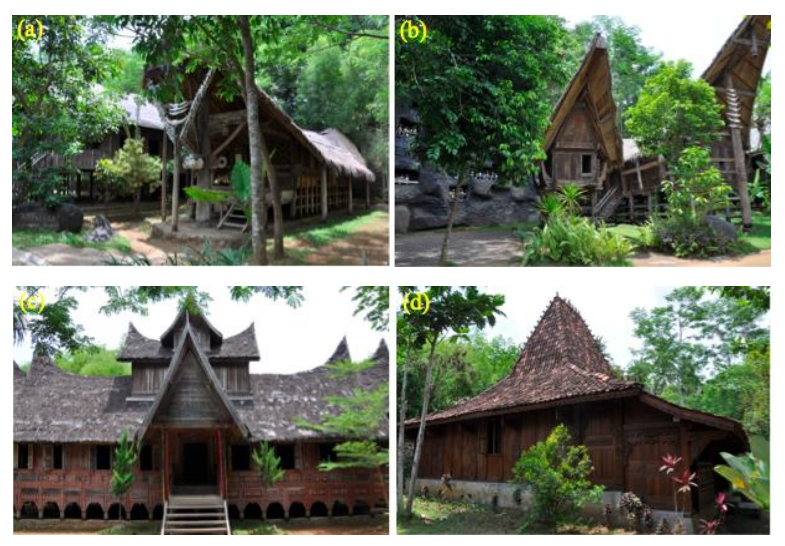

Fig. 4. Several native homes that flown to Taman Nusa; (a) Banua layuk of Mamasa (b) Tongkonan of Toraja (c) Rumah Gadang of Minangkabau (d) Blora house

Here, visitors are offered to explore the long history of Indonesian nation in the eight-point spread area. The tour begins from pre-historic age, continue to the kingdom era which represented by the miniature of Borobudur. Then goes to the Cultural Village, which contains around 60 collections of vernacular houses from Papua, Nusa Tenggara, Maluku and Bali. Then continues to the collections from Sulawesi, Kalimantan, Sumatra, Java and ends at Betawi's home. Next, proceed to the beginning of Indonesian era, where the Chinatown settled alongside with the Gajah Mada statue. The trip then entered for Indonesia's independence period, where the statue of the first president Soekarno and his vice Mohammad Hatta stands. After that, visitors are invited to the point of Indonesian present-day. In this point, dis- 
played diorama, the dynamics of Indonesian life today, social, economic, political, etc. On the last point, visitors can enjoy a contemporary building that will show Indonesia in the future, contains Batik, Puppets and others Indonesian modern art collections.

In the cultural village, visitors not only could see the architectural magnificence of the houses but also the daily life of the native people from respective houses. There are craftsman who makes handicrafts such as woven fabrics (at Nusa Tenggara's home), ship miniature in bottles (at Southeast Sulawesi's home), traditional house miniature keychain (at Jawa Timur's home), how to make Batik (at Yogyakarta's pendopo) and so forth (figure 5). In addition, there are traditional-clothed staffs from the respective ethnic groups to act as the householders. Another interesting feature is the musical instrument and sometimes dance performance that accompanies visitors looking around these buildings.

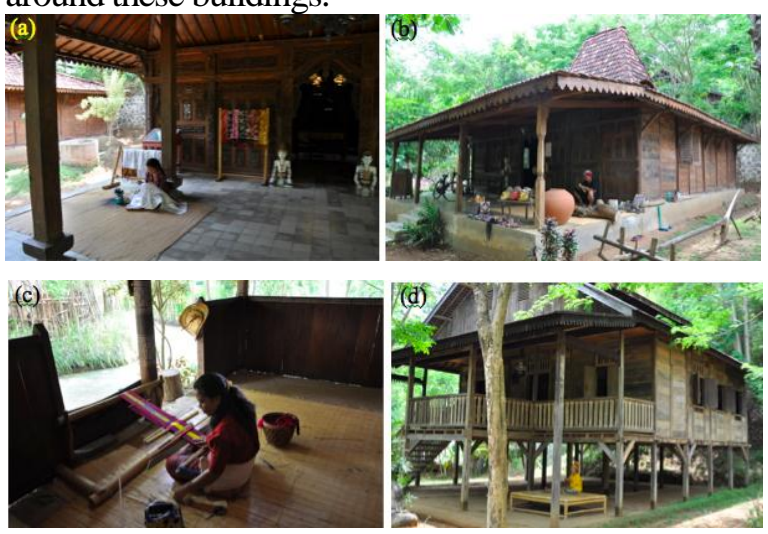

Fig. 5. Performed activities at each house; (a) Batik making at Jogja's pendopo (b) Carving at Jawa Timur's home (c) Weaving fabrics at Amarasi's home (d) Bamboo weaving at Souraja

The location of Taman Nusa in Gianyar, which is known with its thick hilly geography and as one of the most tourism hotspot in Bali makes a point plus for its development and sustainability. The placement of vernacular houses also was made tunes to site's contour and arranged according provincial locations, so it is seen as an Indonesian map.

\section{METHODOLOGY}

This research used the qualitative method, which emphasized on primary data obtained from field surveys. Data such as photographs and interview results from TB Silalahi center in Balige, Sumatera Utara and Taman Nusa in Gianyar, Bali, has been examined critically by using the criteria for open-air museum that previously described. Furthermore, criticism also used in describing a phenomenon that occurs in both cases, so descriptive and interpretive criticism (Attoe, 1979) seems appropriate to be used in analyzing this case. This research also extends the explanation of Indonesian open-air museum that aroused by Raswaty (2009) and taking 'application research variety' that offered by Boyer (in Poggenpohl, 2015). Poggenpohl (2015) said, "There is often a gap between research results and their application in a practical project. This requires interpretation of the results and how they play into a specific project". Thus, with using these two museums, this research describes some indications and the consequences from these rising open-air museums as the first institution in Indonesia that conserve vernacular houses in an ex-situ manner.

\section{RESULTS AND DISCUSSION}

Based on the previous description of both museums, by applying previously described criteria of open-air museum, portrayed below (table 2) how TBSC and Taman Nusa fulfill the criteria to be included as an open-air museum.

From the previous table, it seems these two discussed cases, indeed could be classified as open-air museum for all of the displayed collection that offered at there being showed outdoor. Especially these both museums concern to preserve culture and implicated on its collection that focused on conserving vernacular houses in an ex-situ manner. However, if subsequently examined in-depth, there are several critics as a response to different concepts that applied by both museums, and significant to be considered to see the extent to which the concept of ex-situ conservation can be properly implemented in Indonesia.

Concerning documented collections, both in TBSC and Taman Nusa, unfortunately, there are no proper documentation displayed about the process of reconstruction to the visitors. The process of dismantling, removal and reassembly of Ruma and Sopo to the TBSC's site only based on conventional method (photographs) by simply relying on traditional carpenter without any experts get involved. Not surprisingly, there are many adjustments found, such as nails as reinforcement and new materials such as boards, square beams and zinc roof to substitute fibers, which is damaging its authenticity. Fortunately, fibers still used by one Ruma (no. 3) and one Sopo (no. 4) and still left intentionally mossy to keep the humidity for dried season reason. Likewise in Taman Nusa, there is also nothing documentation displayed on how their original house being translocated. Whereas, this is an effective way of educating visitors about the preservation effort that being carried out. 
Table 2. Comparison aspect of Open-air museum to the cases

\begin{tabular}{|c|c|c|}
\hline $\begin{array}{l}\text { Aspect of Open- } \\
\text { air Museum }\end{array}$ & $\begin{array}{l}\text { TB Silalahi Center } \\
\text { Balige, Sumatera Utara }\end{array}$ & $\begin{array}{l}\text { Taman Nusa } \\
\text { Gianyar, Bali }\end{array}$ \\
\hline Features & $\begin{array}{l}\text { A collection of buildings consists of; TB Silalahi's life } \\
\text { path Museum, Batak Museum, Huta Batak, the } \\
\text { Siwaluh Jabu, the Tongkonan, Pendopo and some } \\
\text { supporting facilities such as restaurant, souvenir shop } \\
\text { and children's playground. }\end{array}$ & $\begin{array}{l}\text { A collection of buildings consists of; a miniature of } \\
\text { Borobudur, modern ethnographic museum, transportation } \\
\text { museum, Nusantara house complex, monuments and statues, } \\
\text { restaurant, café, theater, souvenir shop, and supporting } \\
\text { buildings that stand separately. }\end{array}$ \\
\hline Purposes & $\begin{array}{l}\text { Public oriented with the aim to preserve the Batak } \\
\text { culture and shape the character of the Batak people, } \\
\text { especially for the younger generation, as well as a } \\
\text { place to develop ideas to help improve Batak people's } \\
\text { lives, in the scope of social, economic, and education, } \\
\text { as well as a place for tourism. }\end{array}$ & $\begin{array}{l}\text { Taman Nusa is a cultural tourist park that provides } \\
\text { comprehensive knowledge about the diversity of cultures of } \\
\text { Indonesia's various ethnic, in a natural atmosphere of Bali. } \\
\text { Its mission is to make the park as a cultural preservation, } \\
\text { recreational and didactic for visitors to better understand } \\
\text { about Indonesian culture in an interesting and interactive } \\
\text { way. }\end{array}$ \\
\hline Location & $\begin{array}{l}\text { Settled in a } 5 \text { Ha sloping open area in the Silalahi } \\
\text { village, Balige, Sumatera Utara. With Lake Toba as a } \\
\text { background, this museum strengthens the } \\
\text { characteristics of the place. The view also integrated } \\
\text { into the building of Batak Museum. }\end{array}$ & $\begin{array}{l}\text { Settled in a } 15 \text { Ha open area in the foothills of Sidan village, } \\
\text { Gianyar, Bali. Against Gianyar hills, buildings in this } \\
\text { museum anchored on a cliff, hidden behind leafy trees along } \\
\text { Melangit river. }\end{array}$ \\
\hline Collections & $\begin{array}{l}\text { Indoor: } \\
\text { TB Silalahi's life path museum building contains the } \\
\text { private collection of TB Silalahi from childhood to be } \\
\text { a successful minister. While, inside the building of } \\
\text { Batak museum contains many historical collections } \\
\text { and relics of Batak tribe, equipped with a description } \\
\text { of its history. } \\
\text { Outdoor: } \\
\text { Huta Batak consists of } 3 \text { Ruma and } 4 \text { Sopo which are } \\
\text { hundred of years old, moved from its original location } \\
\text { aroud Toba lake. There is also a Siwaluh Jabu which is } \\
\text { also original and transferred directly from its location } \\
\text { in Karo and a new built Tongkonan. }\end{array}$ & $\begin{array}{l}\text { Indoor: } \\
\text { Ethnographic modern museum building which contains } \\
\text { collections of traditional weavings, traditional music } \\
\text { instruments, and wayang. There is also a transportation } \\
\text { museum diorama featuring Indonesian trains miniature. } \\
\text { Outdoor: } \\
\text { The village of Nusantara contains houses from Papua, Nusa } \\
\text { Tenggara, Bali, Maluku, Sulawesi, Kalimantan, Sumatera } \\
\text { and Jawa. From } 60 \text { Nusantara houses that built in situ by } \\
\text { traditional carpenter involved, there are } 8 \text { original hundred- } \\
\text { years old homes that relocated from its respective area. }\end{array}$ \\
\hline Displaying & $\begin{array}{l}\text { Besides exhibiting private collections of Mr. TB } \\
\text { Silalahi and collections of relics Batak tribe indoor, the } \\
\text { museum also displaying its collection outdoor, such } \\
\text { as: Huta Batak, Siwaluh jabu and Tongkonan. In Huta } \\
\text { Batak, traditional Batak's dance often performed } \\
\text { particularly when welcoming guests and during } \\
\text { incidental festival. }\end{array}$ & $\begin{array}{l}\text { In Taman Nusa there are replicas of traditional houses from } \\
\text { various regions in Indonesia. Some of them are original } \\
\text { house that relocated directly from their respective areas. } \\
\text { In each pavilion of these traditional houses, visitors can } \\
\text { witness traditional dances from various ethnic cultures of } \\
\text { Indonesia. There are also artisans who make payable } \\
\text { handicrafts from each respective region. }\end{array}$ \\
\hline
\end{tabular}

On its progress, unfortunately, there has been no proper maintenance of these buildings, especially in Huta of TBSC. In some parts, weathering began to occur in several poles at Sopo and holed by wood boring blue beetle for its nest (figure 6a-b). Precautions still rely on diesel fuel that brushed in whole structures. The absence of experts and proper method make this modest technique still continually used, albeit on the other hand very vulnerable to fire. Also, the depletion of fibers accelerates the weathering effects on the structure underneath (figure $6 \mathrm{c}$ ). These same considerations underlie many people change fibers with corrugated tin roofs as happened in other three of Sopo.

Concerning the site arrangement, TBSC seemed to adopt the 'growth and development concepts' a la TMII. Seen from the placement of the building which follows the history of the establishment of each building. In TBSC complex, TB Silalahi life path museum built as the first, followed by some support- ing facilities, then Huta Batak and the last is contemporary-shaped Batak Museum. Indeed, this concept is properly used by museums whose have limited funding, but requires more extensive development. However in TBSC case, has not well implemented in planning the entire museum, particularly in arranging the site plan.
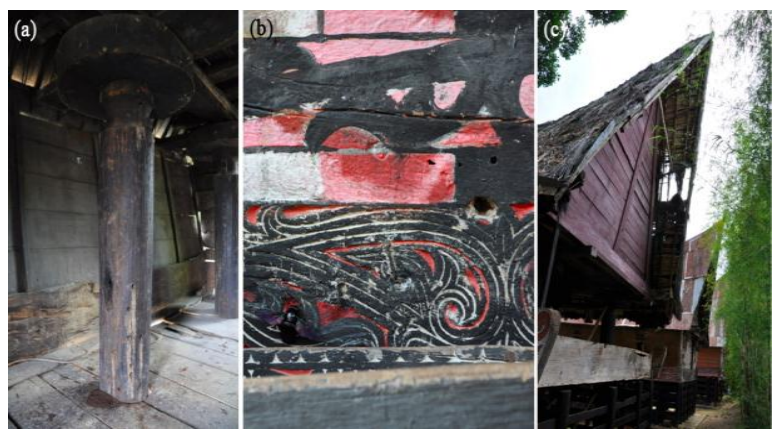

Fig. 6. (a) Holed pole in Sopo (b) A bettle tries to hole Gorga (c) Decayed fibers roof at the oldest Sopo (S4) 
The setting of the landscape seems to be not well arranged (figure 7). Some buildings at there were arranged according to the availability of space and to what kind of the new prospected buildings to be built next. It can be seen from the placement of Siwaluh jabu and pendopo that was built later, which is seemed simply to fill the vacant area of the site. Consequently, in some points at the area has formed unclear circulation pattern as well as closes potential view that can be optimized later by the new constructions. It also becomes a problem that faced by the management to keep the scenery of Lake Toba. As the manager said, existed wetland surround the site has been continually degraded by the land ownership. It is feared that if this happens continuously, the view to Lake Toba will be disturbed. The efforts of TBSC management by purchase several plots of land could not sustain due to financial conditions and the price increasingly crept up.

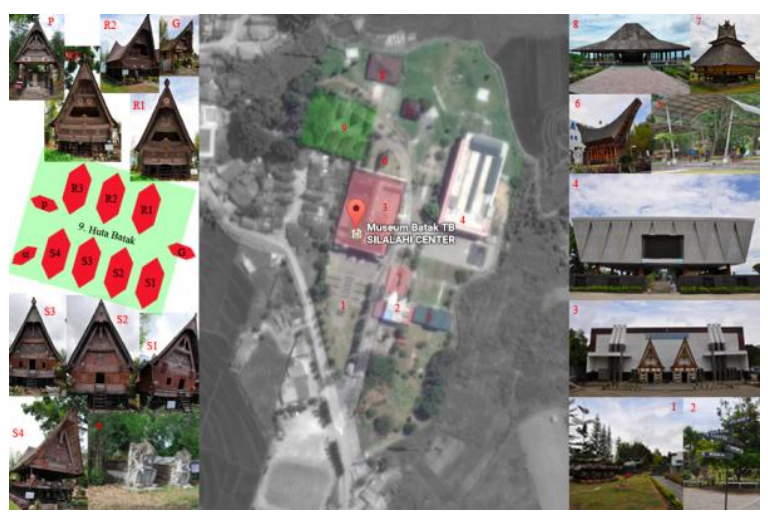

Fig. 7. The site plan of TBSC and its collections

In contrast to Taman Nusa, which is due to its location in slope-contoured site, it is essential to establish a fixed site plan since it pertains to the type of the houses that need to be conserved and the consequences of its position. For example, as seen in the conserved Ngada house of NTT, which is laid to the elevated sloped plain, likened with its original condition. But, this concept has a disadvantage in adding additional facilities due to the limited area of site. Besides of the fixed master plan, need further adjustments in managing the path if later there are some additional features, either collections or facilities added.

In the other hand, quite pity some vernacular houses at there was made new without any effort to match with its real conditions to the origin. Modern material, such as square wooden beams and nails found in several constructions so it creates a less viscous impression when entering this house (figure 8). Coupled with the translocating process of original houses was intended in a conventional way since there is no documentation displayed and communicated to the visitors.

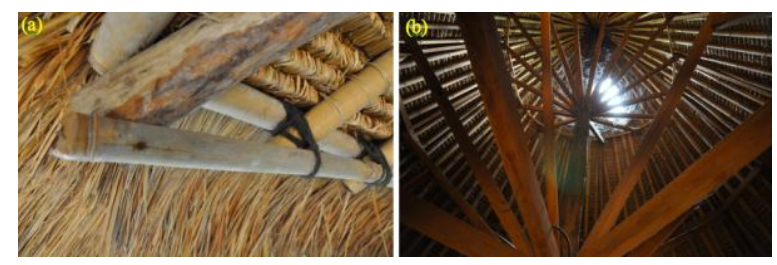

Fig. 8. Some modern modification; (a) Bamboo nailed at rafter (b) Square wooden beams encircling central pole of Mbaru Niang

Meanwhile, on the accessibility arrangement in Taman Nusa, at the moment before going trough to the collections, there are several obscured directions. It ensue when entering the pre-history section, which is not well oriented, coupled with a pointless display (only exhibiting rock and artificial caves) makes visitors wondering 'what shall we see here?'. Ahead, unclear path occurred after the miniature of Borobudur before entering the Nusantara house complex. Here, visitors are exposed of two directions, whether it should walk to the cultural village first or directly go to the future of Indonesia gallery. The next indistinct lane found in front of Rumah Gadang, where visitors who are tired after taking approximately 600 meters walk (the length of the sites from north to south) tend to prefer bypass, which consequently miss the two homes of Riau (figure 9). Actually, there are free guides provided, but due to limited resources, unable
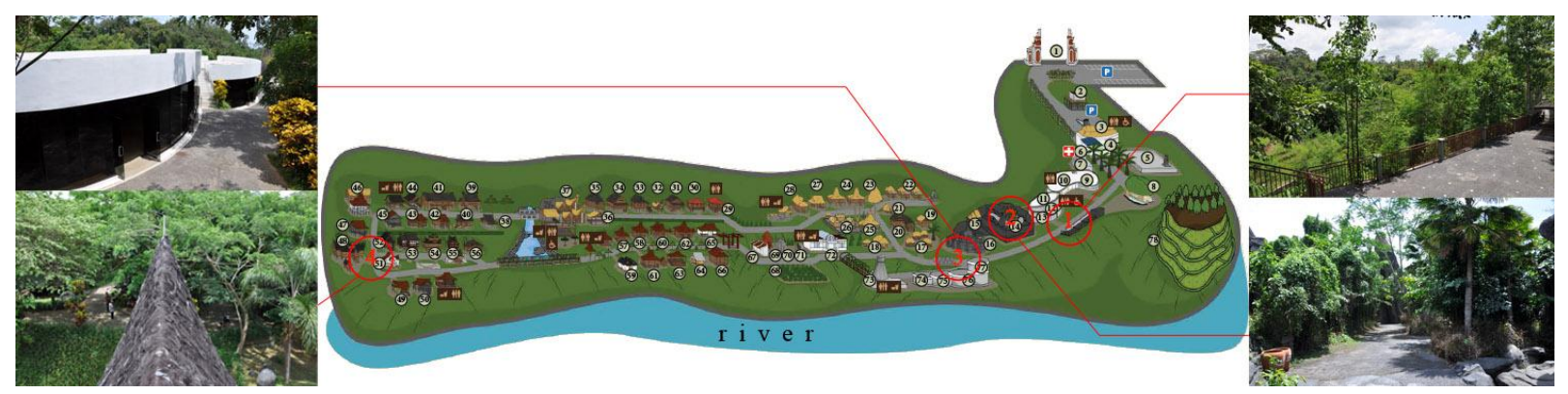

Fig. 9. Some obscured directions in Taman Nusa 
to handle all alternate visitors. Some tourists, especially local travelers, also not too pleased if guided and prefer to explore the site privately.

During author's visitation, found several facilities in these both museums that seemed less maintained. As seen in TBSC, found a bucket to harvest rainwater from a leaky roof inside the life path of TB Silalahi building. Moreover, considering of Ruma Bolon fires by lightning in 2011, fire-fighting facilities are also quite difficult to find around the site. In Huta, there are only two fire extinguishers. Whereas, the availability of fire-fighting units is very vital since everything at there is made of flammable materials.

While in Taman Nusa, some support facilities seemed to set properly, such as the toilets placement in some locations which are not far apart. Also, several recreational cafes can be used to get a rest. But unfortunately, some others began to look less maintained as founded in the prehistory area and an artificial waterfall under Tongkonan house. Related to firefighting, almost same as found in TBSC, only few fire extinguishers found and one of it, placed under a house which is obviously affecting the vista.

Fortunately, neither of these museums saves their collections of historical objects inside the house. Quite risky if the collection is stored inside these wooden houses. Besides the safety factor related to the structure, it will also complicate the safety of the collection itself. As happened in TBSC in 2011, when the first Rumah Bolon was fired due to lightning. However, auspiciously most of the collection inside the house had removed before the fires.

In both cases there are also people who are acting like natives. These acting peoples, who mostly brought from their respective ethnic group, are required to give the impression that this collection can still be occupied, although it is not entirely right because at night they go home. They also play a direct role in introducing their respective culture through performances such as handicrafts making, dance or music. In contrast with TBSC, this native only showed up when special guests or organized tourists in an amount of numbers come in. It is important to be considered in terms of its continuity. As seen at Huta Batak, where weaving workshop displayed beneath of one Ruma has been dormant due to not often visited by visitors. According to the manager, only certain times many visitors come, like in the museum's anniversary.

In Taman Nusa, performances in the amphitheater only displayed if organized before the visit. Of course, with the terms and conditions such as a minimum number of visitors due of related to the preparation of the players, the dancers, the musicians and others. However, one interesting thing in Taman Nusa is the existence of its native people in each home. Besides as an artisan, their presence also to help visitors find out information about the house. Especially when visiting Bali house and West Java house, where visitors pampered with harmoniously Rindik and Angklung by a number of traditional musicians.

Regarding the maintenance, the supervision and continuation is also the subject key to be considered. For example, the role of cleaners should be optimized in controlling the collected houses, especially toward the parts that start to decay, as seen at TBSC. Besides their main task of cleaning the site, these peoples could able to evaluate initial conditions. Meanwhile in Taman Nusa, since each house tenanted by craftsmen, inevitably oversight of maintenance is more optimal.

Taman Nusa is relatively new compared to TBSC and supported by substantial source of funding. Not surprisingly, Taman Nusa offers more variations of the vernacular houses as its collection. This diverseness and comprehensiveness become the main focus to offer for the visitors. At first glance, the diverseness of Taman Nusa's collection seems difficult to administer, but their focus on the international tourism market and the exuberant location in Bali makes it seems easier to succeed. However this is only momentary assessment, depending on the readiness of the management ahead to make many attractive and innovative programs in order to attract more visitors for coming.

Unlike in TBSC, which only offers Batak's house, thus not so many variations could be adored. However, this is the uniqueness of TBSC, which shoud be dug deeper, as embedded in their mission to save the Batak culture. But slightly odd with the existence of Tongkonan, despite mentioned to describe their ancestral relationship with the Torajans. Coupled with the existence of Javanese 'Pendopo' located beside Huta Batak, which according to the manager, will be used as the mausoleum of Mr. T.B. Silalahi and his Javanese wife later.

Indeed, according to the manager, funding is the main constraint for the TBSC management to grasp many burdensome during this time. Until now, TBSC still depend on the finances of the TB Silalahi foundation. Backboned with variety businesses, especially tourism, TB Silalahi foundation still backing up routine fee so that have not been fully able to adapt properly appropriate conservation methods. Moreover, the local government does not provide any regular financial support to improve this potency. During this time, events that were often conducted 
only rely on funding from submitted proposals to public and private companies, as the manager said.

\section{CONCLUSION}

Not an easy way to translocate vernacular houses in Indonesia. Besides the geographical conditions, costly processes are overshadowed, coupled with many obstacles in maintaining ahead. Viewing the phenomenon that occurs in TBSC and Taman Nusa, requires ambition, strong desire and tough idealism to realize this such vision. The desire and hard work of each founder makes this kind museum could be achieved, and into the ranks as the first instituted open-air museum in Indonesia that conserve vernacular houses in an ex-situ manner. Though with its advantages and disadvantages, both show great roles in conserving Indonesian culture and its legacy for future generations.

Concerning the building's placement, both museums apply different approaches. TBSC with its concept of 'growth and development', makes the arrangement of buildings on the site is less directional and creates vagueness directions. Indeed, this concept is suitable to be applied to the growth museum like TBSC. But it needs judiciousness in adding new building later, moreover, the site is surrounded by the beautifulness vista of Lake Toba, which is it should be optimized. While in Taman Nusa, the fixed plan that had been settled before construction, makes disadvantage in adding new building or facilities in the future. Coupled with the site that anchored on a cliff, makes some adjustment should reconsider comprehensively in adding more construction. But behind that, this placement makes Taman Nusa offer a blend of charming architecture and nature that is supposed to exist in the identity of Nusantara architecture.

Meanwhile, the existence of native-acted people is very essential and of course it is necessary to keep it continually exist since their presence help in making traditional atmosphere as well as makes visitors can resonate with the real life of the past. Their presence also helps the visitors to comprehend more about their respective local culture and amply creating jobs for local residents.

But regrettably, the absence of the documentation regarding translocation process of some original buildings at both museums makes an effort in sustaining these cultures became tactless. There is no proper way to follow a standardized procedure and also in documenting those processes, whereas this is the main key in educating public about the whole process of translocation. It also makes the repair process in maintaining phase just follow the standards that usually exist in the community, without any targeted, measurable and systematic process.

From both cases, we can see the financial factor plays an important role. TBSC, which patronized by the TB Silalahi foundation, indeed still able to support TBSC despite of limitations especially in handling maintenance issues. While in Taman Nusa, which is under the management of PT. Taman Nusa, also owned by the one of Indonesian successful businessman, have a wide range of financial to do more improvisation. Coupled with the location of Taman Nusa in Bali, which is indeed a potential market for tourism, making not difficult to grasp their market share. Although Lake Toba had just designated by the President as one of the international tourism destinations, but still need a long way for TBSC to perceive their market share, but at least the chance has been widened open.

Moreover, the purpose of this both museums is only still limited for tourism and basic education about history, not yet for the main task like the improvement of conservation itself. At least, what happened to the structure of Ruma and Sopo at TBSC should encourage many related institutions and academician to get involved in preserving this heritage, especially on how to conserve the wooden structure. Ahead, there should be collaborations between the museum, academia and practitioners for sustaining conservation effort of these vernacular houses. Besides could reduce the expenditure regarding the maintenance cost with such of joint workshops, on the other hand, all supporting documentation in the translocation process could be a part of documenting effort in sustaining cultures as well as a medium in educating public on how the next generation can do this kind conservation method.

\section{REFERENCES}

Atkinson, F. (1987), The Beamish Open Air Museum. Museum International, 39, pp. 132-138. doi:10.1111/j.1468-0033.1987. tb00683.x

Attoe, W. (1978). Architecture and Critical Imagination. John Wiley \& Sons.

Hitchcock, M. (2005). We will know our nationbetter: Taman mini and nation building in Indonesia. Civilisations, 52-2 |2005, pp. 45-56.

Kerlogue, F. (2008). House Form and Ethnic Identity: Tradition and Variation in House Style in Jambi Province. Indonesian Houses, 2, R. Schefold, P.J.M. Nas, G. Domenig, R.Wessing. KITLV Press, Leiden, pp. 343-344.

Oliver, P. (2001). Re-Presenting and Representing the Vernacular: The Open-Air Museum. Consum- 
ing, Tradition, Manufacturing Heritage: Global Norms and Urban Forms in The Age of Tourism, edited by N. AlSayyad, Routledge, London, pp. 191-211.

Poggenpohl, S.H. (2015). Communities of Practice in Design Research. She ji: The Journal of Design, Economics, and Innovation, Issue No.1, Autumn 2015. Tongji University, pp. 44-57.

Raswaty, R. (2009). Konsep Museum Situs dan Openair Museum: Tinjauan Kasus Pada Taman
Arkeologi Onrust, Museum Situs Kepurbakalaan Banten Lama, dan Taman Mini Indonesia Indah. Thesis, Universitas Indonesia.

Rentzhog, S. (2007). Open Air Museums: The History and Future of a Visionary Idea. Jamtli Förlag, Sweden.

Yusran, Yusfan A. (2016). The Ebb Tide in Conserving Nusantara Architecture. Procedia Engineering, 161, pp. 1343-1352. http://dx.doi.org/ 10.1016/j.proeng.2016.08.654. 